\title{
Lipids, fatty acids composition and carotenoids of Chlorella vulgaris cultivated in hydroponic wastewater
}

\author{
By Fabiano Cleber Bertoldi*, Ernani Sant’Anna, Maurício Villela da Costa Braga \\ and Jorge Luiz Barcelos Oliveira
}

\author{
Laboratório de Biotecnologia Alimentar, Departamento de Ciência e Tecnologia de Alimentos, \\ Universidade Federal de Santa Catarina, Rod. Admar Gonzaga 346, CEP 88034-001, \\ Itacorubi, Florianópolis, Santa Catarina, Brasil. E-mail: fabianobertoldi @ hotmail.com
}

\section{RESUMEN}

Lípidos, composición de ácidos grasos y carotenos en Chlorella vulgaris cultivadas en solución hidropónica residual

Medios de cultivo alternativos vienen siendo evaluados para el cultivo de microalgas, entre ellos, están los afluentes industriales y agrícolas, que posibilitan la reciclaje del residuo, bioconvirtiéndose en una biomasa enriquecida bajo el punto de vista nutricional, que puede ser utilizada como complemento alimenticio, para la acuacultura y en varias otras áreas de actuación. El presente trabajo tuvo como objetivo determinar los contenidos de lípidos, composición de ácidos grasos y carotenoides producidos por la microalga Chlorella vulgaris cultivada en solución hidropónica residual, con diferentes diluciones. Los resultados de los contenidos de lípidos totales no presentaron diferencia significativa. Los ácidos grasos predominantes fueron los 16:0, 18:0, 18:1 e 18:3n-6. Para los carotenoides totales, la dilución de la solución hidropónica residual no estimuló la producción de estos pigmentos por la microalga. La utilización de la solución hidropónica residual como medio de cultivo alternativo para Chlorella vulgaris genera buenas perspectivas para la producción de lípidos, ácidos grasos y carotenoides.

PALABRAS-CLAVE: Ácidos grasos - Carotenoides Chlorella vulgaris - Hidropónica - Lípidos - Microalga.

\section{SUMMARY}

Lipids, fatty acid composition and carotenoids of Chlorella vulgaris cultivated in hydroponic wastewater

Alternative culture media have been evaluated for the cultivation of microalgae, among them are, industrial and agriculture wastewaters, that make residue recycling possible by bioconverting it into a rich, nourishing biomass that can be used as a feeding complement in aquaculture and in diverse areas. The objective of this research is to determine the lipid, fatty acid profile and carotenoid produced by the microalgae Chlorella vulgaris cultivated in a hydroponic wastewater, with different dilutions. The results showed that lipid contents did not present significant differences. Fatty acids were predominantly 16:0, 18:0, 18:1 and $18: 3 n-6$. For total carotenoids, the dilution of hydroponic wastewater did not stimulate the production of these pigments. From this study, it was determined that, the use of hydroponic wastewater as an alternative culture medium for the cultivation of Chlorella vulgaris generates good perspectives for lipid, fatty acid and carotenoid production.

KEY-WORDS: Carotenoid - Chlorella vulgaris - Fatty acid Hydroponic - Lipid - Microalgae.

\section{INTRODUCTION}

An american called William Gericke suggested the word hydroponic to indicate the cultivation of plants in a liquid medium, making the cultivation of plants without soil popular in the 30's (Jones Jr, 1982). However, the nutritive solution that feeds the plants, in the hydroponic technique, needs to be periodically replaced, offering a potentially nutritive residue solution.

Alternative cultivation media have been evaluated for the cultivation of Chlorella; among them are industrial wastewater, biodigestor wastewater, digested mud and domestic waste material (Pipes and Gotaas, 1960; Rodulfo et al., 1980; Wong and Lay, 1980; Jussiak et al., 1984; Sánchez et al., 2001).

Some micro algae present a larger fatty acid spectrum, when compared to oleaginous plants, containing a molecular structure with even more than 18 carbons (Belarbi et al., 2000). They generate good perspectives for oil production and may produce thirty times more oil than soybean per unit area. However, its major importance is related to the quality of the produced fatty acids, where most of them are composed of unsaturated fatty acids, like linolenic, eicosapentaenoic acid (EPA) and docosahexaenoic acid (DHA) (Skjak-Braek, 1992).

Prior studies showed fatty acid profile variations in microalgae species. This can be observed in response to different growth conditions (FernándezReiriz et al., 1989; Volkman et al., 1989; Dunstan et al., 1993).

Few studies have been done to explore biochemical diversities among microalgaes; nevertheless, they are important potential sources 
of vitamins, fuel, chemistry, pharmacological products and antibiotics due to their high lipid, pigments and protein contents (Beneman, 1990).

The production of an algal biomass is not considered to be low cost. However, its profit compensates the investments, due to the value of some metabolites which can reach high prices on the international market (Borowitzka, 1990).

Fatty acids and carotenoids extracted from the microalgae can be offered with different purity contents, incorporated into other products or encapsulated, like in the docosahexaenoic acid market obtained from Crypthecodinium cohnii microalgae (Borowitzka, 1999).

Considering that the nutritive solution that feeds the plants in the hydroponic technique needs to be replaced periodically generating a kind of wastewater with macro and micronutrients in it, this experiment aimed at the evaluation of this wastewater as a potential cultivation medium to obtain lipids, fatty acids and carotenoids through Chlorella vulgaris microalgae.

\section{MATERIALS AND METHODS}

\subsection{Algal culture}

The Chlorella vulgaris studied was donated by the Ficology Laboratory of the Federal University of São Carlos. The cultivation medium used in the maintenance of the microalgae was Bold's Basal Medium (BBM) which contained the following: $\mathrm{mgL}^{-1}$ : $\mathrm{NaNO}_{3}, 250 ; \mathrm{KH}_{2} \mathrm{PO}_{4}, 175 ; \mathrm{CaCl}_{2} \cdot 2 \mathrm{H}_{2} \mathrm{O}, 25$; $\mathrm{MgSO}_{4} \cdot 7 \mathrm{H}_{2} \mathrm{O}, 75 ; \mathrm{K}_{2} \mathrm{HPO}_{4}, 75 ; \mathrm{NaCl}, 25 ; \mathrm{EDTA}, 50$; $\mathrm{FeSO}_{4} \cdot 7 \mathrm{H}_{2} \mathrm{O}, 4.98 ; \mathrm{H}_{3} \mathrm{BO}_{3}, 11.42 ; \mathrm{ZnSO}_{4} \cdot 7 \mathrm{H}_{2} \mathrm{O}$, 8.82; $\mathrm{NaMoO}_{4} \cdot 2 \mathrm{H}_{2} \mathrm{O}, 0.72 ; \mathrm{CoCl} \cdot 6 \mathrm{H}_{2} \mathrm{O}, 0.38$; $\mathrm{MnCl}_{2} \cdot 4 \mathrm{H}_{2} \mathrm{O}, 1.44 ; \mathrm{CuSO}_{4} \cdot 5 \mathrm{H}_{2} \mathrm{O}, 1.57$; thiamine, 10, biotine, 0.1 ; vitamin $\mathrm{B} 12,0.01$ and the $\mathrm{pH}$ adjusted to 6.8 .

\subsection{Experimental installation}

Cultures were kept under constant aeration, at a controlled temperature of $25 \pm 2{ }^{\circ} \mathrm{C}, \mathrm{pH} 6,8$ and continuous light of $150 \mu \mathrm{mol}$ photon $\mathrm{m}^{-2} \mathrm{~s}^{-1}$, coming from 40w fluorescent light bulbs.

A volume of $180 \mathrm{~mL}$, having a cellular density of $2.5 \times 10^{6}$ cellmL ${ }^{-1}$ of Chlorella vulgaris in BBM medium, was inoculated in inverted conic photobioreactors containing $3700 \mathrm{~mL}$ of four different cultivation media: BBM, which was considered as the reference cultivation; hydroponic wastewater (HW), diluted hydroponic wastewater $1: 1$ (50\% residue to $50 \%$ deionized water) denominated as HW50 and diluted hydroponic wastewater $1: 3$ (25\% residue to $75 \%$ deionized water) called HW25. To eliminate bacteria and protozoa, hydroponic wastewater was filtered and sterilized by autoclaving it for 20 min. Four independent repetitions were conducted for each treatment. The hydroponic wastewater was obtained from the Laboratory of
Hydroponic of the Federal University of Santa Catarina, with its chemical characterization expressed in Table 1.

Table 1

Physical and chemical characteristics of hydroponic wastewater

\begin{tabular}{lc}
\hline Parameters & Mean value \\
\hline $\mathrm{pH}$ & 5.0 \\
Conductivity & $1.9 \mathrm{mScm}^{-1}$ \\
Chemical Oxygen Demand & $23.94 \mathrm{mgL}^{-1}$ \\
Biochemical Demand of Oxygen & $5.40 \mathrm{mgL}^{-1}$ \\
Ammonia & $26.60 \mathrm{mgL}^{-1}$ \\
Nitrates & $226.50 \mathrm{mgL}^{-1}$ \\
Nitrites & $0.27 \mathrm{mgL}^{-1}$ \\
Total phosphorus & $35.00 \mathrm{mgL}^{-1}$ \\
\hline
\end{tabular}

\subsection{Analytical methods}

The total content of Carotenoid was extracted from the fresh biomass with $90 \%$ acetone and determined by a spectrophotometric method according to the methodology developed by Strickland and Parsons (1972).

The cellular density was determined by counting the number of cells with light microscopy using a Neubauer Hematocytometer.

The lipid determination was done according to the methodology described by Bligh and Dyer (1959), where solvents used in the extraction were chloroform-methanol in a proportion of $1: 2(\mathrm{v} / \mathrm{v})$.

From the extract obtained in the total lipid determination, the transesterification of the fatty acids was done according to the procedures developed by Hartman and Lago (1973). Fatty acid methyl esters were analyzed by gas chromatography with a flame ionization detector (Varian Star $3400 \mathrm{CX}$ ), nitrogen was used as the carrier gas in a fused-silica capillary column DB-WAX (J\&W Scientific) $30 \mathrm{~m}$ long and with a $0.32 \mathrm{~mm}$ inner diameter with an immobilized polyethylene glycol film thickness of $0.25 \mu \mathrm{m}$.

The operational conditions programmed were: initial column temperature of $50{ }^{\circ} \mathrm{C}$ for 2 minutes, elevated to $250{ }^{\circ} \mathrm{C}$ at a rate of $10^{\circ} \mathrm{C}$ per minute, kept at the final temperature for 20 minutes. The temperature of the detector was $300{ }^{\circ} \mathrm{C}$ and the injector had a temperature of $t 250{ }^{\circ} \mathrm{C}$. Fatty acids were identified through the comparison of time retention with standards (Supelco).

\subsection{Statistics Analysis}

The statistics analysis was done using the variance analysis (ANOVA) and Tukey test, in a confidence level of $95 \%(p<0.05)$, in order to show the differences between the means of each treatment. 


\section{RESULTS}

Table 2 shows the results of the lipid and carotenoid contents produced by Chlorella vulgaris microalgae in different media after seven days of cultivation.

Although lipid contents did not show any significant differences ( $p>0.05$ ), the microalgae cultivated in HW25 presented the highest content among the other hydroponic wastewater solutions.

In a comparison of total carotenoid values, it was observed that the HW and HW50 cultivations presented higher contents, being significantly different $(p<0.05)$ from BBM and HW25 cultivations. While the concentration of total carotenoids produced in HW25 showed lower contents among the microalgae cultivated in hydroponic wastewater, this treatment did not show significant difference $(p>0.05)$ in relation to the control culture (BBM), indicating the feasibility of carotenoid production using this culture medium.

Table 3 shows Chlorella vulgaris, fatty acid composition after seven days of cultivation in different media The fatty acids 16:0, 18:0, 18:1 and 18:3n-6 were the ones found in larger concentrations. The other fatty acids were presented in smaller quantities, except for 20:0 from HW treatment and fatty acid 20:5 cultivated in HW25.
Table 2

Lipids and carotenoids synthesis in Chlorella vulgaris after seven days of cultivation in the medium control (BBM) and in the hydroponic wastewater solutions.

\begin{tabular}{lcc}
\hline & $\begin{array}{c}\text { Total lipids } \\
\text { (\%) }\end{array}$ & $\begin{array}{c}\text { Total carotenoids } \\
\text { (pgcell-1) }\end{array}$ \\
\hline BBM & $18.21 \pm 1.36^{\mathrm{a}}$ & $0.039 \pm 0.008^{\mathrm{a}}$ \\
HW & $15.80 \pm 1.72^{\mathrm{a}}$ & $0.066 \pm 0.007^{\mathrm{b}}$ \\
HW50 & $15.02 \pm 1.70^{\mathrm{a}}$ & $0.071 \pm 0.010^{\mathrm{b}}$ \\
HW25 & $17.41 \pm 1.89^{\mathrm{a}}$ & $0.040 \pm 0.008^{\mathrm{a}}$ \\
\hline
\end{tabular}

Means with equal letters in the same column do not differ statistically among themselves $(p>0.05)$.

Date are given as mean values \pm standard deviation of the means.

The percentage of saturated fatty acids of HW25 cultivation showed a significant difference $(p<0.05)$ when compared to HW and HW50 cultivations. It showed that the microalgae cultivated in HW25 presented a lower quantity of saturated fatty acids. On the other hand, it was the one that had the highest content of unsaturated fatty acids, as well as polyunsaturated fatty acids, but did not show significant difference $(p>0.05)$, except for HW.

Table 3

Composition (\%) of fatty acids in the lipid fraction extracted from Chorella vulgaris after seven days of cultivation in the medium control (BBM) and in the hydroponic wastewater solutions

\begin{tabular}{|c|c|c|c|c|}
\hline Fatty acids & BBM & HW & HW50 & HW25 \\
\hline $14: 0$ & $N D^{*}$ & 0.97 & 2.79 & 0.70 \\
\hline $14: 1$ & ND & 1.56 & 0.64 & ND \\
\hline $16: 0$ & 19.20 & 17.05 & 20.64 & 18.54 \\
\hline $16: 1$ & 0.87 & ND & ND & 0.35 \\
\hline $17: 0$ & 4.19 & ND & ND & 1.05 \\
\hline $17: 1$ & 1.25 & ND & ND & 1.25 \\
\hline 18:0 & 14.60 & 11.88 & 11.74 & 4.70 \\
\hline $18: 1$ & 12.66 & 15.21 & 4.81 & 10.82 \\
\hline $18: 2$ & 3.77 & 3.39 & 8.48 & 8.14 \\
\hline $18: 3 n-6$ & 21.09 & 16.03 & 14.74 & 24.42 \\
\hline $18: 3 n-3$ & ND & 2.56 & 5.00 & 0.20 \\
\hline $20: 0$ & 0.36 & 17.52 & 7.84 & 5.13 \\
\hline $20: 1$ & 4.09 & 1.87 & 6.70 & 2.28 \\
\hline $20: 2$ & 3.91 & 0.45 & 5.59 & 2.01 \\
\hline $20: 3$ & 3.30 & ND & 1.19 & 0.45 \\
\hline $20: 5$ & 2.10 & 1.90 & 0.62 & 7.86 \\
\hline $22: 1$ & 0.05 & ND & 0.06 & 0.22 \\
\hline $24: 0$ & ND & ND & 0.55 & 0.25 \\
\hline $22: 6$ & ND & ND & 0.58 & ND \\
\hline Total saturated & $38.35^{a, b}$ & $47.42^{a}$ & $43.56^{a}$ & $30.37^{b}$ \\
\hline Total unsaturated & $53.09^{a, b}$ & $41.41^{\mathrm{a}}$ & $47.77^{a, b}$ & $58.00^{b}$ \\
\hline Total monounsaturated & $18.92^{\mathrm{a}}$ & $18.64^{\mathrm{a}}$ & $12.21^{b}$ & $14.92^{b}$ \\
\hline Total polyunsaturated & $34.17^{\mathrm{a}}$ & $24.33^{b}$ & $36.20^{a}$ & $43.08^{a}$ \\
\hline
\end{tabular}

Values with equal letters in the same lines do not differ statistically among themselves $(p>0.05)$.

* ND: not detected. 


\section{DISCUSSION}

The dilution of the hydroponic wastewater causes the reduction of important nutrients, like nitrogen and phosphorus. This nutrient deficiency causes lipids to be preferentially synthesized, resulting in a higher accumulation of fat in the algae cells (Rigano et al., 1998). With nitrogen reduction in the medium, a diminishing of the amino acid quantity in the cell occurs, consequently increasing the percentage of lipids (Mandalam and Palsson, 1998).

In another study done by Santos et al. (2003), it was observed that lipid contents decrease in Spirulina maxima microalgae from 23.16 to $8.35 \%$ with a drastic increase in nitrogen concentration from zero to $2.5 \mathrm{gL}^{-1}$. However, there was a lower variation in lipid content when the nitrogen concentration remained between zero and $0.2 \mathrm{gL}^{-1}$.

Piorreck et al. (1984) observed that nitrogen concentration diminishing in a green algae medium, including Chlorella vulgaris, lead to a lipid increase, reaching approximately $45 \%$.

Lipid production and accumulation in microalgae involve specific factors for each species and cultivation conditions. Nevertheless, based on the results found in the literature, it is suggested that lipid content increases due to the limiting factor of nitrogen levels.

Although the results have shown that the lipid contents increased as hydroponic wastewater was diluted, they did not present any significant difference $(p>0.05)$ among treatments. This indicates that the metabolism of Chlorella vulgaris was not significantly affected by lipid synthesis when cultivated in this medium.

The total carotenoid contents in Chlorella vulgaris are coherent with the ones found in the literature, where values vary from 0.03 to 0.08 pgcell $^{-1}$ in a study done by Rioboo et al. (2002). It was observed that hydroponic wastewater dilution unstimulated this pigment production by microalgae. Studies show that nitrogen makes the accumulation of carotenoid viable in some microalgaes (Del Campo et al., 2000).

We can conclude that the use of hydroponic wastewater as a Chlorella vulgaris alternative culture medium generates potential perspectives for the production of lipids, fatty acids and carotenoids.

\section{ACKNOWLEDGMENTS}

We wish to take this opportunity to acknowledge CNPq for PhD fellowship and PETROBRAS for their support (project N. ${ }^{\circ} 360-2002$ ).

\section{REFERENCES}

Belarbi, E.H, Molina, E., Chisti, Y. 2000. A process for high yeld and scaleable recovery of high purity eicosapentaenoic acid esters from microalgae and fish. Process Biochem. 35, 951-969.
Beneman, J.R. 1990. Microalgae products and production: an overview. Dev. Ind. Microbiol. 31 (5), 247-256.

Bligh, A., Dyer, W. J. 1959. A rapid method of total lipid extraction and purification. Can. J. Biochem. Physiol. 37, 911-917.

Borowitzka, I.J. 1990. Status of the Australian algal biotechnology industry in 1990. Australian J. Biotechnol. 4 (4), 239-240.

Borowitzka, M.A. 1999. Commercial production of microalgae: ponds, tanks, tubes and fermenters. $J$. Biotechnol. 70, 313-321.

Del Campo, J.A., Moreno, J., Rodríguez, H., Vargas, M.A, Rivas, J., Guerrero, M.G. 2000. Carotenoid content of chlorophycean microalgae: factors determining lutein accumulation in Muriellopsis sp. (Chlorophyta). J. Biotechnol. 76, 51-59.

Dunstan, G.A., Volkman, J.K., Barret, S.M., Garland, C.D. 1993. Changes in the lipid composition and maximization of the polyunsaturated fatty acid content of three microalgae grown in mass culture. J. Appl. Phycol. 5, 71-83.

Fernández-Reiriz, M.J., Perez-Camacho, A., Ferreiro, M.J., Blanco, J., Planas, M., Campos, M.J., Labarta, U. 1989. Biomass production and variation in the biochemical profile (total protein, carbohydrates, RNA, lipids and fatty acids) of seven species of marine microalgae. Aquaculture 83, 17-37.

Hartman, L., Lago, R.C.A. 1973. Rapid preparation of fatty methyl esters from lipids. Lab. Pract. 22, 475-476.

Jones Jr., J.B., 1982. Hydroponics: its history and use in plant nutrition studies. J. Plant Nutrition. 5, 1003-1030.

Jussiak, M.P., Duszota, K., Mycielski, R. 1984. Intensive culture of Chlorella vulgaris as the second stage on biological purification of nitrogen industry wastewater. Water Res. 18, 1-7.

Mandalam, R.K., Palsson, B. 1998. Elemental balancing of biomass and medium composition enhances growth capacity in high-density Chlorella vulgaris culture. Biotechnol. Bioeng. 59, 605-611.

Piorreck, M., Baasch, K., Pohl, P. 1984. Biomass production, total protein, chlorophylls, lipids and fatty acids of freshwater green and blue-green algae under different nitrogen regimes. Phytochemistry 23, $207-$ 216.

Pipes, W.O., Gotaas, H.B. 1960. Utilization of organic matter by Chlorella grown in seawage. Appl. Microbiol. 8,163-169.

Rigano, V.D.M., Vona, V., Esporito, S., Carillo, P., Carfagna, S., Rigano, C. 1998. The physiologican significance of light and dark $\mathrm{NH}_{4}{ }^{+}$metabolism in Chlorella sorokiniana. Phytochemistry 47, 177-181.

Rioboo, C., González, O., Herrero, C., Cid, A. 2002. Physiological response of freshwater microalga (Chlorella vulgaris) to triazine and phenylurea herbicides. Aquat. Toxicol. 59, 225-235.

Rodulfo, B.R., Marmol, N.H.R., Emralino, G.A. 1980. Production of Chlorella in clarified effluent from hog manure biogas digester. Phillipp J. Sci. 109, 51-58.

Sánchez, S., Martinez, M.E., Espejo, M.T., Pacheco, R. 2001. Mixotrophic culture of Chlorella pyrenoidosa with olive-mill wastewater as the nutrient medium. $J$. Appl. Phycol. 13, 443-449.

Santos, G, M., Macedo, R. V. T., Alegre, R. M. 2003. Influência do teor de nitrogênio no cultivo de Spirulina maxima em duas temperaturas - Parte I: Alteração da composição da biomassa. Ciênc. Tecnol. Aliment., 23, 17-21. 
Skjak-Braek, G. 1992. Alginates - biossynthesis and some structure function relationships relevant to biomedical and biotechnological applications. Biochem. Soc. Trans. 20, 27-33.

Strickland, J. D. H., Parsons, T. R. 1972. A practical handbook of seawater analysis. Bull. Fish. Res. Bd. Can., 2nd Ed., 167.

Volkman, J.K., Jeffrey, S.W., Nichols, P.D., Rogers, G.I., Garland, C.D. 1989. Fatty acid and lipids composition of 10 species of microalgae used in mariculture. $\mathrm{J}$. Exp. Mar. Biol. Ecol. 128, 219-240.

Wong, M.H., Lay, C.C. 1980 . The comparison of soybean wastes using tea leaves and seawage sludge for growing Chlorella pyrenoidosa. Environ. Pollut. 23, 247-259.

Recibido: Septiembre 2005 Aceptado: Enero 2006 